\title{
THE LEGALITY OF INTERRELIGIOUS MARRIAGE IN THE PERSPECTIVE OF ISLAMIC LAW AND INDONESIAN POSITIVE LAW
}

\author{
Muchammad Ichsan \\ Lecturer at Faculty of Law \\ Universitas Muhammadiyah Yogyakarta \\ E-Mail: drichsan65@yahoo.com
}

\begin{abstract}
This study aims at examining the legality of interreligious marriage according to Islamic law and Indonesian positive law. To reach the goal set by this research, a descriptive method is used in the writing while an analytical method is employed to scrutinize the relevant problems. This study finds that interreligious marriage has spread widely among Indonesians that it has now become a phenomenon. However, Islam does not recognize a Muslim woman's marriage unless she is married by a man belonging to the same religion, i.e. a Muslim. A Muslim man is not permitted to marry a mushrik (polytheist) woman. It is lawful for him to marry a woman from the Ahlul Kitaab (Jews and Christians), but Indonesian ulemas prohibit such a marriage as well because of the negative outcomes. Meanwhile, the 1974 Indonesian Marriage Law fails to address the issue of interreligious marriage in a clear manner. This brings forth at least three interpretations: firstly, the law does not regulate interreligious marriage at all; secondly, the law allows it; and thirdly, the law denies it. Through an analysis, the last interpretation is found to have stronger reasons than the others.
\end{abstract}

Key Words: Legality, Interreligious, Marriage, Islamic Law, Indonesian Positive law

Abstrak: Penelitian ini bertujuan untuk menguji legalitas pernikahan antaragama menurut hukum Islam dan hukum positif Indonesia. Agar tercapai tujuan yang diinginkan, maka penelitian ini menggunakan metode deskriptif untuk menganalisis masalah yang sedang diteliti. Studi ini menemukan bahwa pernikahan antaragama telah menyebar luas di kalangan masyarakat Indonesia yang kini telah menjadi fenomena. Namun, Islam tidak mengenali pernikahan wanita Muslim kecuali jika dia menikah dengan pria yang memiliki agama yang sama, yaitu seorang Muslim. Seorang pria Muslim tidak diizinkan untuk menikahi wanita musyrik (politeis). Dan halal baginya untuk menikahi wanita dari Ahlul Kitaab (Yahudi dan Kristen), namun sebagian ulama Indonesia tetap melarang pernikahan semacam ini, karena beberapa alasan. Sementara itu, Undang-Undang Perkawinan Indonesia 1974 gagal menangani masalah pernikahan antaragama dengan cara yang jelas. Ini setidaknya menghasilkan tiga interpretasi: pertama, hukum sama sekali tidak mengatur pernikahan antaragama; Kedua, hukum mengizinkannya; Ketiga, undang-undang tersebut menolaknya. Melalui sebuah analisis tersebut di atas, disimpulkan bahwa jenis interpretasi yang terakhir ditemukan memiliki alasan yang lebih kuat daripada alasan yang lainnya.

Kata Kunci: Legalitas, antaragama Pernikahan, Hukum Islam, Hukum Positif Indonesia 


\section{INTRODUCTION}

Indonesia comprises so many regions and islands. The inhabitants of this archipelagic country are people from diverse races and ethnic groups. And smooth social intercourse among them makes a marriage between a man and a woman from different islands and ethnic groups a frequent occasion. This in general is deemed normal and not problematic.

What have become problems, however, is marriage between Indonesians who follow different religions and faiths as well as between Indonesian Muslims and foreigners from different religions and cultures. This is now commonplace. And those having interreligious marriages are no longer exclusively from the lower classsuch marriages have also been practiced by the middle class and the highly-educated.

The facts that many forbid it and that the practice in the society is never easy with all the obstacles do not seem to stop a lot of people from entering into interreligious marriage. They believe religious differences should not be a barrier or impediment for the innocent relationship tying two human beings who love one another. As far as there are an agreement, love and affection between the aspiring husband and wife, religious differences are not something to worry about or exaggerate.

Because this issue emerges time after time, and because there are often arguments over it, this paper intends to clarify the legality of interreligious marriage in the perspective of both Islamic law and Indonesian positive law. The matter will be studied through a discussion on the following questions: How is the state of the interreligious-marriage phenomenon in the society? Why have many people gone into it? What are the risks? What is the legality under Islamic law and state law? What are the positives of prohibiting interreligious marriage?

\section{DISCUSSION}

An interreligious marriage refers to a marriage between a man and woman who follow different religions and retain them during the wedlock (Hadikusuma, 2007). Other terms often used for this meaning are different-religion marriage or interfaith marriage.

In general, it can be said that interreligious marriage can be classified into the mixed marriage category. Mixed marriage is a broader sort. Not only does it refer to interreligious marriage, it also covers international marriage and inter-cultural marriage. A mixed marriage is a marriage conducted in Indonesia by intending spouses who are subjects to different sets of laws (Hadikusuma, 2007).

Lately, interreligious marriage has become a phenomenon in the society as many people practice it from time to time. The media, both electronic and print, never miss to report news about it, especially if public figures such as celebrities are concerned. Some examples of those who have gone into interreligious marriage are Jamal Mirdad and Lydia Kandou, Katon Bagaskara and Ira Wibowo, Yuni Shara and Henri Siahaan, Adrie Subono and Crisye, Ari Sihasale and Nia Zulkarnaen, Dedi Corbuzier and Kalina, Frans Mohede and Amara Lingua, Sonny Lauwany and Cornelia Agatha, and many more (Lamandasa, 2011).

Perhaps the main reason for interreligious marriage is because the spouses have fallen in love with each other, thinking they have been tied to one another and inseparable by anything. They believe religious differences cannot and should not obstruct their innocent relationship.

The urge may become more intense for women pregnant before marriage. In such cases, religious law and state law will go out of their consideration to enter into interreligious marriage, because the important thing is to get married soon to avoid embarrassment from having a child without a husband.

Besides, there are Indonesians especially celebrities who seem to love to marry foreigners without paying attention to their religion (Anonim, 2010). They may think that marrying a "bule" (an Indonesian term 
for a person of Caucasian race) represents a pride of its own in front of the public. It may also be thought as offering a fun, new sensation.

\section{The Risks of Interreligious Marriage}

Getting married with a person who follows a different religion may bring many problems and risks to those who insist on doing it. There may be problems such as conflicts within their respective families if they oppose the marriage, social sanctions from the community that tends to disprove interreligious marriage, difficulties in teaching religion for their children, how their kids have to be ready to deal with social sanctions from their surroundings that consider them "illegitimate" (although this term is very inhumane) and, the heaviest one, aloneness and loneliness throughout their life in practicing religion and living their religiousness despite their being together (Ikhsan, 2007).

They will also have many difficulties in taking care of the administrative matters of the marriage. If one of them is a Muslim and the other is not, the Religious Affairs Office (Kantor Urusan Agama/KUA) will not recognize and record it officially because they only register marriages between Muslims. Likewise, many or all of the Registries of Births, Deaths and Marriages (Kantor Catatan Sipil/KCS) in Indonesia will not recognize and record interreligious marriages as they only register marriages between non-Muslims as specified in Government Regulation No. 9 of 1975 Article 2 Section (2).

So the biggest risk of interreligious marriage after family conflicts and social sanctions is its legality under religious law and state law. To get out of this dead lock, many interreligious couples find a way by having one of them converted to their spouse's religion only to go back to their original religion after the marriage. The second way is by undergoing a marriage service under each of the spouses' religions, so they hold two ceremonies. The third is by asking the court to certify their marriage.
And the fourth way is by performing the wedding abroad and registering the marriage at the KCS within 1 year as specified by Article 56 of the Marriage Law (Agung, 2011).

Any of these four ways serves to "legalize" interreligious marriages before the laws and regulations applicable in Indonesia. Furthermore, there are also couples who prefer "kumpul kebo" (cohabitation) or kawin siri (unregistered marriage) (Anonim, 2011). The question is, are all those things permitted by religion? Clearly, is interreligious marriage forbidden or allowed by Islamic law and Indonesian positive law?

\section{Interreligious Marriage in the Perspective of Islamic Law}

Regarding the legality of interreligious marriage in the perspective of Islamic law, there are things that have been agreed on as well as things that are still debated among ulemas. They are as follows:

a. A Marriage between A Muslim Woman and A Non-Muslim Man

According to Islamic law, if a Muslim woman desires to marry, she only has one choice, i.e. to be married by a Muslim man. A man with any religion or faith other than Islam is forbidden for her. This is the judgment of the majority of ulemas, and is even an ijmaa' (consensus) (al-Zuhailiyy, 2006). The source is the command of Allah:

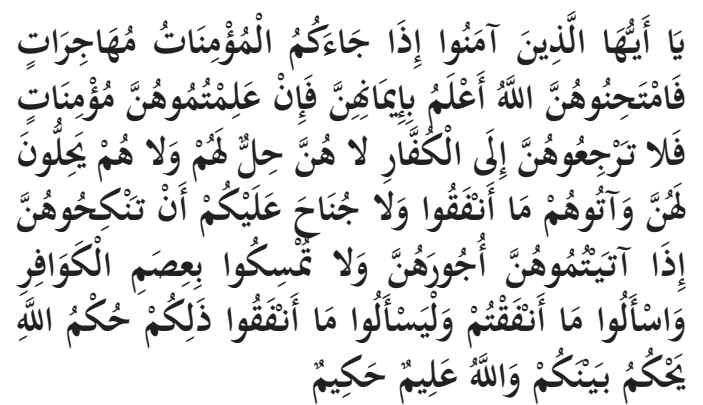

"O you who have believed, when the believing women come to you as emigrants, examine them. Allah is most knowing as to their faith. And if you know them to be believers, then do not 
return them to the disbelievers; they are not lawful [wives] for them, nor are they lawful [husbands] for them. But give the disbelievers what they have spent. And there is no blame upon you if you marry them when you have given them their due compensation. And hold not to marriage bonds with disbelieving women, but ask for what you have spent and let them ask for what they have spent. That is the judgement of Allah; He judges between you. And Allah is Knowing and Wise." (QS AlMumtahanah: 10)

And Allah commands:

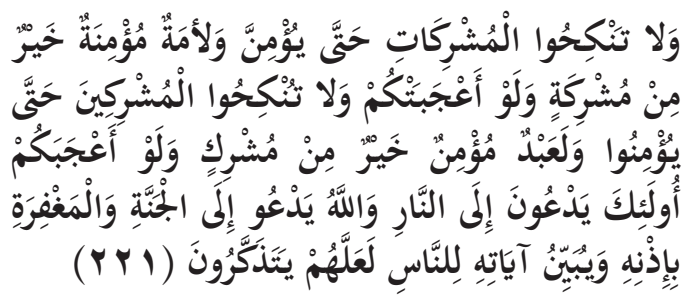

"And do not marry polytheist women until they believe. And a believing slave woman is better than a polytheist, even though she might please you. And do not marry polytheist men [to your women] until they believe. And a believing slave is better than a polytheist, even though he might please you. Those invite [you] to the Fire, but Allah invites to Paradise and to forgiveness, by His permission. And He makes clear His verses to the people that perhaps they may remember." (QS Al-Baqarah: 221)

From the two verses above, it can be concluded that Muslim women are forbidden to be taken as wives by disbelieving or polytheist men. They can only be married by Muslim men.

There is a liberal and "defiant" opinion from some Indonesian Muslims that allows Muslim women to be married by Ahlul Kitaab (Jewish or Christian) men. This view comes from the analogy with the allowance for Muslim men to marry Ahlul Kitaab women as specified in QS Al-Maidah: 5. If Muslim men are allowed to marry Ahlul Kitaab women, the reverse must also be true (Monib \& Nurcholis, 2009). This opinion, nevertheless, is very weak as such analogy deviates from the nash or the explicit Quranic text. Experts on Ushuul al-Figh (Principles of Islamic Jurisprudence) say: "Laa qiyaas ma'a alnash" (There shall be no analogy for nash/Quranic texts or hadiths). The Quranic text in this case is the command of Allah: "they are not lawful [wives] for them, nor are they lawful [husbands] for them" (QS Al-Mumtahanah: 10). In fact, there is already an ijmaa' (consensus) of the Muslim community that it is illegitimate for non-Muslim men to marry Muslim women (Al-Thabariyy, 2000).

Additionally, in the matter of marriage, the principle that should be held is al-ashl fii al-abdhaa'i al-tahriim (the original law for faraj [sexual] matters is forbiddance), not al-ashl fii al-asyaai alibaahah (the original law for anything is allowance) (Yaqub, 2007).

b. Marriage between A Muslim Man with A Non-Muslim Women

Marriages between Muslim men and Non-Muslim women other than the Ahlul Kitaab are obviously forbidden. Among them are polytheist or Wathani women who worship and have gods other than Allah, such as statues, planets, fire or animals. Also forbidden are marriages between Muslim men and atheist or Maddi women, which are ones who worship material objects, disbelieve the existence of Allah and reject Abrahamic religions. Examples of this kind would be communist women and those followers of Wujudi (some kind of pantheism), Bahaism, Ahmadiyya and Buddhism (al-Zuhailiyy, 2006). This is the consensus of the majority of ulemas based on Allah's command:

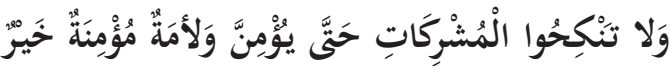




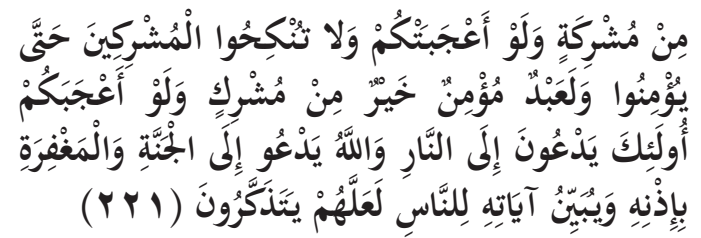

"And do not marry polytheist women until they believe. And a believing slave woman is better than a polytheist, even though she might please you. And do not marry polytheist men [to your women] until they believe. And a believing slave is better than a polytheist, even though he might please you. Those invite [you] to the Fire, but Allah invites to Paradise and to forgiveness, by His permission. And He makes clear His verses to the people that perhaps they may remember." (QS. Al-Baqarah: 221)

This verse distinctly rules that a marriage between a believing man and a polytheist woman is absolutely prohibited, unless the polytheist woman is willing to believe (only in Allah) before it.

As for marriages between Muslim men and Ahlul Kitaab women, although allowed explicitly in QS al-Maidah: 5, it remains a debatable subject among ulemas. Some ulemas allow it while others strongly forbid or at least discourage it.

Those allowing this kind of marriage base their opinion on the following verse of Allah:

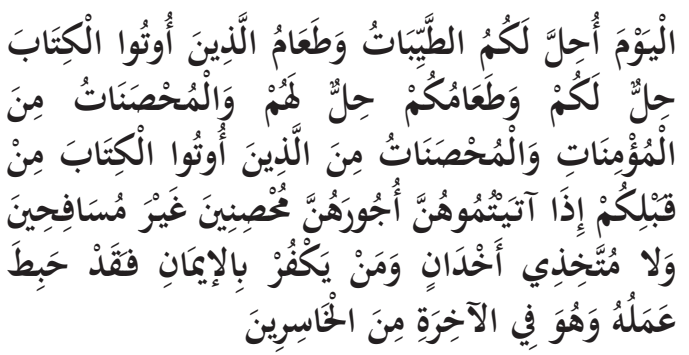

"This day [all] good foods have been made lawful, and the food of those who were given the Scripture is lawful for you and your food is lawful for them. And [lawful in marriage are] chaste women from among the believers and chaste women from among those who were given the Scripture before you, when you have given them their due compensation, desiring chastity, not unlawful sexual intercourse or taking [secret] lovers. And whoever denies the faith - his work has become worthless, and he, in the Hereafter, will be among the losers." (QS Al-Maidah: 5)

In this verse, Allah clearly allows a Muslim man to marry a woman of the Ahlul Kitaab who keeps her honor. And by Ahlul Kitaab it means those who believe in Abrahamic scriptures, which are the Jews and Christians (both Protestant and Catholic). So the Ahlul Kitaab people are Ahlu al-Tauraat wa alInjiil or the believers of the Torah and the Bible (al-Zuhailiyy, 2006).

The ulemas against or disliking marriages between Muslim men and Ahlul Kitaab women in Indonesia are, among others, those from the Indonesian Ulema Council (MUI) and the Muhammadiyah organization. MUI and Muhammadiyah of course knows that Allah allows such marriages in QS Al-Maidah: 5. MUI forbids it somehow by a consideration of maslahah (benefit) and mafsadah (damage). Because the damage that comes from interreligious marriage is thought to be greater than the benefit, forbidding it is thus the better stance. The MUI Fatwa (Ruling) dated June 1, 1980 stipulates as follows: c. Marriage between a Muslim woman and a non-Muslim man is forbidden.

Muslim men are forbidden to marry non-Muslim women. There are different opinions on marriage between a Muslim man and an Ahlul Kitaab woman. However, since the damage is deemed greater than the benefit, the Indonesian Ulema Council decrees that such marriage is forbidden.

Muhammadiyah also forbids marriages between Muslim men and 
Ahlul Kitaab women on the ground of the sadd al-dzaraai' principle. Sadd aldzaraai' is one of the sources of Islamic law that holds an understanding that in order to prevent negative consequences, even a halaal (allowed) matter can be forbidden. This method, according to Muhammadiyah, is seen as an application of a figh principle that reads: Dar'u al-mafaasid muqaddam 'alaa jalb al-mashaalih (the avoidance of damage shall be prioritized over the gain of benefit) (Tim PP Muhammadiyah Majlis Tarjih, 1995).

From the above explanation, it can be said that Muslim women are absolutely forbidden to be married by non-Muslim men. Such is also the case for Muslim men marrying polytheist women. Marriage between a Muslim man and an Ahlul Kitaab woman, meanwhile, is still debated. In the Quran it is clearly allowed, but many ulemas consider it forbidden upon the reason that the damage is greater than the benefit and based on the sadd al-dzaraai' as well as the Dar'u al-mafaasid muqaddam 'alaa jalb al-mashaalih principles. It is this last opinion that most Indonesian ulemas follow and practice.

2. Interreligious Marriage in the Perspective of Indonesian Positive Law

In Indonesia, marriage is regulated by Law No. 1 of 1974. Article 66 of the Law lies down that upon the passing of this Law, the provisions specified in the Indonesian Civil Code (Burgerlijk Wetboek, shortened as BW), Christian-Indonesians Marriage Ordinance (Huwelijks Ordonantie Christen Indonesiers S.1933 No. 74, shortened as HOCI), Mixed Marriage Regulation (Regeling op de gemengde Huwelijken S. 1898 No. 158, shortened as GHR), and other previous regulations concerning marriage are declared invalid, as long as [the matters concerned are] already governed by this Law.

Concerning the legality of marriage, Article 1 Section (2) stipulates, "A marriage is lawful if performed according to the law of the couple's respective religions and beliefs."

The text of this article is thought by legal experts as vague, unclear and inexplicit that it produces at least three interpretations regarding the issue of interreligious marriage.

The first interpretation, interreligious marriage is not regulated by this Law. This kind of marriage is not specified explicitly in any of its articles or sections. Only mixed marriage is regulated, and a mixed marriage according to Article 57 is one carried out in Indonesia between two people who are subjects to different sets of laws due to their nationalities, not religions.

Therefore, as maintained by the supporters of this interpretation, the Supreme Court through its Jurisprudence dated January 20, 1989 No. 1400 K/ Pdt/1986 provides a legal solution for interreligious marriages. The law specifies that certification requests for interreligious marriages can be granted by the Registry of Births, Deaths and Marriages (KCS) as the only institution authorized to register marriages between men and women who are not Muslims (Lamandasa, 2011).

Another solution brought forth is that the law on interreligious marriage shall refer to regulations applicable before the passing of the 1974 Marriage Law. This is in line with Article 66 of the Marriage Law. The sentence "sejauh sudah diatur" ("as long as [the matter concerned are] already governed") in the article could actually mean the Mixed Marriage Regulation (Regeling Op De Gemengde Huwelijken S. 1898 No 158, shortened as GHR) remains in effect, and are there to be used if needed, considering that provisions on interreligious marriage are nonexistent and not specified in the Law No. 1 of 1974 (Anonim, 2011).

If we look closely at the GHR, we will find out that interreligious marriage is allowed. In the GHR Article 7 Section (2), there is a clause that reads: "Differences in religions, nationalities or origins shall not be a hindrance for a marriage." 
The second interpretation, interreligious marriage is allowed by this Law. The reason is that there is no clear prohibition in the law. Prof. H. Hilman Hadikusuma, S.H. believes that a lawful marriage according to the state marriage law is one carried out in compliance with the applicable rules in Islam, Protestantism/Catholicism, Hinduism and Buddhism. The phrase "hukum masing-masing agamanya dan kepercayaannya itu" ("the law of the couple's respective religions and beliefs") means the law of one of their religions, not both of their religions, which are the religions embraced by the spouses and their families.

Despite saying that, Prof. H. Hilman approves interreligious marriages as he further says: "So in case of an interreligious marriage, it is lawful if performed according to the rules of one of the spouses' religions: the bridegroom's or the bride's, but not both of the spouses' or their families' religions. If a marriage has been conducted under Islamic law, but then performed again under Christian law or Hindu/Buddhist law, the lawfulness of this marriage thus becomes annulled, and vice versa (Hadikusuma, 2007).

Another reason consenting interreligious marriage maintains that it belongs to the category of mixed marriage, based on the argument in Article 57 on mixed marriage that puts emphasize on its being done by two people in Indonesia who are subjects to different sets of laws, which means that it could be between two people with different nationalities and/or different religions (Lamandasa, 2011).

Entering into interreligious marriage is also considered a human right. As specified by Article 16 of the UDHR (Universal Declaration of Human Rights), men and women of full age, without any limitation due to race, nationality or religion, have the right to marry and to found a family. They are entitled to equal rights as to marriage, during marriage and at its dissolution. The requirement for this marriage is seen only from the agreement aspect. Marriage shall be entered into only with the free and full consent of the intending spouses. Moreover, according to the UDHR, the family is the natural and fundamental group unit of society. Therefore, this right is entitled to protection by society and the State (See the UDHR on http://bloggerbekasi. com/2010/12/11/deklarasi-universal-hakasasi-manusia.html).

The UDHR clarifies that the exercise of this right shall be done without distinction of any kind, such as race, color, sex, language, religion, political or other opinion, national or social origin, property, birth or other status. Furthermore, no distinction shall be made on the basis of the political, jurisdictional or international status of the country or territory to which a person belongs, whether it be independent, trust, non-self-governing or under any other limitation of sovereignty (Agung, 2011).

The same goes for the ICCPR (International Covenant on Civil and Political Rights). In Article 23 of the ICCPR, it is specified that the family is the natural and fundamental group unit of society and is entitled to protection by society and the state. The right of men and women of marriageable age to marry and to found a family shall be recognized. The fundamental requirement for marriage is the free and full consent of the intending spouses (See the ICCPR on http://www.kontras.org/baru/ Kovenan\%20Sipol.pdf).

In short, entering into marriage is a basic human right that anyone, including the State, shall not interfere. The rejection for interreligious marriage is a discriminative action based on religious reasons. Hence, the State needs to adjust its entire laws and regulations related to the basic rights as a concrete manifestation of recognition for human rights (Agung, 2011).

The third interpretation, interreligious marriage is forbidden by this Law. The reason, Article 2 Section (1) in conjunction with Article 8 Point (f) of Law No. 1 of 1974 stipulates that a marriage is lawful if performed according to the law of each of the couple's religions and beliefs. In the explanation of the article, it is stressed that 
with the passing of Article 2 Section (1), there shall be no marriage non-compliant with the law of the couple's respective religions and beliefs as specified by the 45 Constitution. The provision of the article means that a marriage shall be performed according to the couple's religion(s), and that matters prohibited by the couple's religion(s) shall also be forbidden by the Marriage Law (Lamandasa, 2011).

In line with this, Prof. Dr. Mr. Hazairin interprets Article 2 Section (1) and its explanation that it is impossible for a Muslim to marry in a way that goes against the law of their religion, and so is for a Christian, Hindu and Buddhist (Sudarsono, 2005).

Upon the passing of Law No. 1 of 1974, religious law has become a determinant to the legality of a marriage in Indonesia. This means that a marriage non-compliant with the couple's religion(s) is unlawful. Without following religious law, even a marriage certified by the court or the Registry of Births, Deaths and Marriages is unlawful (Hadikusuma, 2007).

And as explained before, the MUI and Muhammadiyah have forbid marriage between a Muslim man and a non-Muslim woman, in general, and an Ahlul Kitaab woman, in particular, and vice versa. The Rulings of the MUI, despite its being a nonstate institution, are always considered and followed by state institutions such as the Ministry of Religious Affairs, Religious Courts, People's Representatives Council and other bodies.

In practice, moreover, the KUA staff as well as the judges in religious courts also deny and refuse to recognize interreligious marriages. They refer to Presidential Instruction No. 1 of 1991 concerning the Compilation of Islamic Law (KHI). The prohibition on interreligious marriage is clearly specified in a number of $\mathrm{KHI}$ articles as follows.

KHI Article 40 Point (c) stipulates: "It is prohibited for a man and a woman to enter into marriage in any of the following conditions: (c) the bride is not a Muslim."
And Article 44 stipulates: "A Muslim woman is forbidden to marry a non-Muslim man."

And Article 61, concerning the prevention of marriages, stipulates: "A difference in status cannot be a reason to prevent a marriage, except the difference in status is due to religious dissimilarity or ikhtilaaf al-diin."

And Article 75 Point (a) states: "The decision on the annulment of marriage does not apply retroactively to: (a) Marriage that is annulled because either the husband or the wife leaves Islam" (See the KHI on http://pdfdownloadfree.net/).

The bases for the prohibition on interreligious marriage in the $\mathrm{KHI}$ are: firstly, the view that interreligious marriage may cause many problems stemming from the principal differences between the spouses. There are indeed couples in interreligious marriages who manage to live harmoniously while maintaining their marital bonds, but this minority should not become a reference in the establishment of law as it is an exception. Secondly, the KHI follows the judgment of Indonesian ulemas, including the MUI (Anonim, 2010).

\section{ASSESSMENT}

After observing and considering the three interpretations above and their respective reasons, it can be concluded that the strongest interpretation is the third that prohibits interreligious marriage. This is because its reasons are more rational and acceptable. Besides, it can be added here that:

Marriages must be conducted according to the law of one of the official religions in Indonesia, which are Islam, Protestantism, Catholicism, Hinduism, Buddhism and Confucianism, and therefore an atheist's marriage will not be recognized.

The stipulation that marriages must be conducted according to religious law clearly means what is prohibited by religion is also prohibited by marriage law. So in the case of interreligious marriage, whether it is allowed or not depends on religious law. 
Article 2 Section (1) and the explanation show that for Muslims there is no possibility to marry in a way that goes against their own religious law, and so is for Christians, Hindus, Buddhists and Confucians.

In response to the argumentation of the First Interpretation, it can be said that Supreme Court's Jurisprudence dated January 20, 1989 No. 1400 K/Pdt/1986, which provides a legal solution for interreligious marriage, contradicts Government Regulation No. 9 of 1975 Article 2 Section (2). Likewise, the GHR that approves interreligious marriage, if applied, violates the prohibition by religion, particularly Islam. The GHR's stipulation, thus, should not be implemented.

In response to the argumentation of the Second Interpretation, it can be said that what is meant by a mixed marriage in the Marriage Law is explicitly defined in Article 57 , i.e. a marriage conducted in Indonesia between two people who are subjects to different sets of laws due to differences in nationalities, not religions. Mixed marriage, thus, should not be made a justification or rationalization for interreligious marriage. Regarding human rights, it can be said that although entering into interreligious marriage is a human right that cannot be intervened by anyone, including the State, there seems to be a difference in the conception of marriage between the Human Rights Law and the Marriage Law. On one hand, the Human Rights Law only requires that the intending spouses have free and full consent while, on the other hand, the Marriage Law stipulates that there are further requirements other than the spouses' free and full consent. Moreover, the Human Rights Law does not clarify the basic principles of marriage. The explanation for Article 10 Section (1) states that what is meant by "a lawful marriage" is one conducted in compliance with the applicable laws and regulations. (See Law No. 39 of 1999 concerning Basic Human Rights and the Explanation on http:// www.kemenkumham.go.id/attachments/ article/170/uu39_1999.pdf).It means that a marriage is lawful if it abides by the provisions in the Marriage Law, that is to say, lawful from the perspectives of religion and positive law.

Although in the 1974 Marriage Law there is no explicit prohibition on interreligious marriage, in practice the KUAs, the KCSs and the Courts firmly refuse to process interreligious marriages. This demonstrates that there is the same understanding, i.e. interreligious marriage is not recognized, not acknowledged and not approved in Indonesia. If there are cases where a KCS or Court does the contrary, they are anomalous in nature, very limited in number and must have been opposed by many.

A marriage abroad, as specified by Article 56 of Law No. 1 of 1974, between Indonesian citizens living overseas or between an Indonesian and a foreign citizen, is considered lawful provided that it obeys the law applicable in the country where the marriage is conducted and, for Indonesians, does not infringe this Law. The last clause "and, for Indonesians, does not infringe this Law" shows that the legality of the marriage depends both on the law applicable in the country of occurrence and the Marriage Law. If it is not in compliance with both sets of laws, the marriage will be considered unlawful and cannot be registered at the KCS. An example of this would be an Indonesian Muslim woman who is married by a non-Muslim man in Europe or another place overseas. This marriage is considered unlawful for disobeying religious law.

\section{The Positives of the Prohibition on Interreligious Marriage}

After providing supports for the third interpretation that maintains interreligious marriage is forbidden and a violation to the Marriage Law, described below are some positives of prohibiting interreligious marriage.

Religion is one of the five essentials (al-dharuuriyyaat al-khams) for human life that has to be protected for the sake of their happiness in the world and in the afterlife. With this in mind, marriage should be first 
in compliance with religious law before state law.

One of the requirements for the legality of marriage for Muslim women based on the verdict of the majority of ulemas is their spouse must be a Muslim. This is because there is a very realistic concern about the woman converting into her husband's religion if he is not a Muslim.

The purpose of marriage is to establish a happy and lasting family (household) on the basis of Belief in the One and Only God. Can it be achieved by a husband and wife who follow different religions? If it is possible in the world, what about the afterlife? It needs to be emphasized here that Islam aims at happiness in both the world and the afterlife.

The religious difference between a husband and wife entails further differences, such as those in the belief or faith aspect, in prayer and the procedures, in morals and behaviors, and in everyday affairs like clothing and food and drinks. There are indeed interreligious couples who manage to live in harmonious marriage, but this minority should not become a reference in the establishment of law as it is an exception (Anonim, 2010).

The prohibition on interreligious marriage is a preventive action institutionalized in a governing system, on the basis of the negative realities in society as follows: firstly, a Muslim husband or wife converting into their wife or husband's religion; secondly, children following their mother's non-Islam religion; thirdly, concerns that this kind of marriage according to Sayyid Qutub may give birth to a generation that turn away from Islam or according to Buya Hamka children that are spiritually broken. It is even likely that due to the spouses' mutual lenience, both of them abandon their religions, which may eventually cause their children to have no clear religion as well (Netralikum, 2008).

\section{CONCLUSION}

Interreligious marriage as a phenomenon is becoming more and more concerning overtime. Interreligious marriage could not have existed in the society if Article 2 Section (1) of the 1974 Marriage Law were specified clearly and explicitly. The unclearness and inexplicitness of this Article on the legality of marriages has raised multiple interpretations and resulted in the government's hesitant stance in regulating marriages for the people. The government's ambivalence on interreligious marriage can be seen in the fact that if a marriage is not recognized by the Religious Affairs Office, it can be certified through the court or recorded at the Registry of Births, Deaths and Marriages or, in the case of an interreligious marriage, carried out abroad.

Therefore, it is suggested that Article 2 Section (1) of the 1974 Marriage Law concerning the legality of marriages be clarified and made more explicit in order to avoid multiple interpretations, ambiguity and confusion. And what is more important, such clarification is needed so that there will be no uncertainty in refusing interreligious marriage.

Furthermore, Islamic social ethics should be introduced early on to Muslim teenagers to avoid negative consequences. If every Muslim is aware of and follows the ethics, interreligious marriages can be prevented.

\section{REFERENCES}

Al-Thabariyy, Muhammad bin Jarir, 2000, Jaami' al-Bayaan Fii Takwiil al-Qur'aan, Beirut: Muassasah al-Risaalah.

Al-Zuhailiyy, Wahbah, 2006, Al-Figh al-Islaamiyy wa adillatuh, Beirut: Daar al-Fikr, 4th Print.

Hadikusuma, Prof. H. Hilman, SH., 2007, Hukum Perkawinan Indonesia, Bandung: Mandar Maju.

Monib \& Nurcholis, Mohammad \& Ahmad, 2009, Kado Cinta Bagi Pasangan Nikah Beda 
Agama, Jakarta: PT Gramedia Pustaka Utama.

Sudarsono, Drs., SH., M.Si, 2005, Hukum Perkawinan Nasional, Jakarta: Rineka Cipta.

Tim PP Muhammadiyah Majlis Tarjih, 1995, Tanya Jawab Agama, Yogyakarta: Suara Muhammadiyah.

Yaqub, Prof. KH. Ali Mustafa, MA, 2007, Nikah Beda Agama Dalam Al-Qur'an \& Hadis, Jakarta: Pustaka Firdaus.

\section{Websites}

Agung, dr. Agus Putu, 2011, Kasus Pernikahan Beda Agama, http://indohukum.blogspot. com/2011/04/kasus-pernikahan-beda-agama.html, retrieved on 8 Feb 2013 at 11.00

Anonim, 2010, Perkawinan Beda Agama Menurut Pandangan Islam, http://rangerwhite09artikel.blogspot.com/2010/04/hukumnya-wanita-muslim-kawin-dengan.html, retrieved on 8 Feb 2013 at 14.00

Anonim, 2011, Kawin Beda Agama, Mengapa Tidak ? http://irindonesia.wordpress. com/2011/01/06/kawin-beda-agama-mengapa-tidak/, retrieved on 8 Feb 2013 at 16.00

Ikhsan, Asnawi, 2007, Nikah Beda Agama, http://wb13.wordpress.com/2007/09/05/niikahbeda-agama/, retrieved on 8 Feb 2013 at 15.00

Lamandasa, Raimond Flora, 2011, Perkawinan Beda Agama Di Indonesia, http://www.scribd. com/doc/3144824/Perkawinan-Beda-Agama-Di-Indonesia, retrieved on 8 Feb 2013 at 13.00

MUI, 1980, Fatwa tentang Perkawinan Campuran, http://www.

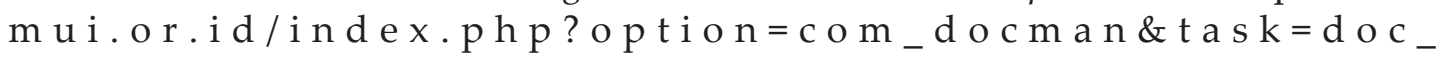
view\&gid=24\&tmpl=component\&format=raw\&Itemid=73, retrieved on 8 Feb 2013 at 16.00

Netralikum, 2008, Pernikahan Lintas Agama, http://indonesia.faithfreedom.org/forum/ pernikahan-lintas-agama-t29329/, retrieved on 8 Feb 2013 at 13.00

\section{Laws and Regulations}

Law No. 1 of 1974 concerning Marriage and the Explanation

Law No. 39 of 1999 concerning Basic Human Rights and the Explanation

Government Regulation No. 9 of 1975 concerning the Implementation of Law No. 1 of 1974 concerning Marriage

Presidential Instruction No. 1 of 1991 concerning the Compilation of Islamic Law

Mixed-Marriage Regulation (Regeling op de gemengde Huwelijken S. 1898 No. 158, shortened as GHR)

Universal Declaration of Human Rights (UDHR)

International Covenant on Civil and Political Rights (ICCPR) 